\title{
Farnesyl Diphosphate Analogues with w-Bioorthogonal Azide and Alkyne Functional Groups for PFTase-Catalyzed Ligation Reactions
}

\author{
Guillermo R. Labadie ${ }^{\dagger}$, Rajesh Viswanathan, and C. Dale Poulter ${ }^{*}$ \\ 315 South 1400 East RM 2020; Department of Chemistry; University of Utah, Salt Lake City, UT, \\ USA 84112
}

\begin{abstract}
Eleven farnesyl diphosphate analogues, which contained $\omega$-azide or alkyne substituents suitable for bioorthogonal Staudinger and Huisgen [3+2] cycloaddition coupling reactions, were synthesized. The analogues were evaluated as substrates for alkylation of peptide co-substrates by yeast protein farnesyl transferase. Five of the diphosphates were good alternative substrates for FPP. Steady-state kinetic constants were measured for the active compounds, and the products were characterized by HPLC and LC-Mass. Two of the analogues gave steady state kinetic parameters ( $\mathrm{k}_{\mathrm{cat}}$ and $\mathrm{K}_{\mathrm{M}}$ ) very similar to those of the natural substrate.
\end{abstract}

\section{INTRODUCTION}

Posttranslational modification of proteins to append isoprenoid chains to enhance their association with membranes is required in a variety of important biological processes, including signal transduction pathways controlling cell growth and differentiation, cytoskeletal rearrangement, membrane rearrangement during cellular division, vision, and vesicular transport. Approximately $1 \%$ of mammalian proteins are modified at a C-terminal cysteine residue by $\mathrm{C}_{15}$ farnesyl or $\mathrm{C}_{20}$ geranylgeranyl groups. ${ }^{1}$ Among the prenylated proteins that have been identified are nuclear lamins, the $\gamma$-subunit of heterotrimeric small $\mathrm{G}$ proteins such as transducin, the Ras super family of small $\mathrm{G}$ proteins, and enzymes such as protein tyrosine phosphatases, inositol polyphosphatases, and phospholipase A.

Several prenylated proteins are implicated in human diseases. Ras proteins function as an on/ off switch to regulate a variety of cellular functions, including proliferation. In approximately $30 \%$ of human cancers, mutations in Ras compromise its ability to hydrolyze GTP to GDP, and the persistently active GTP-bound protein contributes to the development of cancer. ${ }^{2,3}$ Ras proteins are farnesylated on the cysteine sulfur of their C-terminal CAAX box, where A is often an aliphatic residue and $\mathrm{X}$ is typically either serine or methionine (alanine, glutamine, threonine, and in certain cases, leucine can also serve as the $\mathrm{X}$ residue). Farnesyltransferase inhibitors have been advanced to clinical trials as anticancer agents. ${ }^{4,5}$

Recent reports suggest that the nuclear blebbing seen in cells from patients with HutchinsonGilford progeria syndrome (HGPS) results from a mutation that prevents maturation of lamin A by blocking proteolytic cleavage of a farnesylated C-terminal 15 amino acid peptide. 6,7 Protein prenylation has also been identified as a target for antiparasitic agents. 8,9 Protein

*Corresponding author. Phone: 801-581-6685; FAX 801-581-4391.

${ }^{\dagger}$ Present address: IQUIOS-CONICET, Universidad Nacional de Rosario, Suipacha 531, 2000, Rosario, Santa Fe, Argentina. 
farnesyl transferase (PFTase) inhibitors have shown high potency against the parasites responsible for malaria (P. falciparum $)^{10,11}$ and the Chagas' disease parasite T. cruzi. ${ }^{12,13}$

The modification reactions are catalyzed by three different protein prenyl transferases: PFTase (EC 2.5.1.58), protein geranylgeranyltransferase-I (PGGTase-I, EC 2.5.1.59), and Rab (a Raslike protein) geranylgeranyltransferase (RabGGTase or PGGTase-II, EC 2.5.1.60). The closely related PFTase and PGGTase-I transfer prenyl groups from prenyl diphosphates to proteins containing a C-terminal CAAX motif, (also known as a CAAX box) where $\mathrm{C}$ is cysteine, $\mathrm{A}$ is usually a small aliphatic amino acid, and $\mathrm{X}$ can be a variety of amino acids (Figure 1 ). The $\mathrm{X}$ residue determines whether a farnesyl $(\mathrm{X}=\mathrm{A}, \mathrm{S}, \mathrm{C}, \mathrm{M}, \mathrm{Q})$ or a geranylgeranyl $(\mathrm{X}=\mathrm{L}, \mathrm{F})$ is added. ${ }^{14}$

The rational design of FPP analogues for PFTase with specific functions has been facilitated by the X-ray crystal structures for the rat ${ }^{15}$, and human ${ }^{16}$ PFTases. Spielmann and coworkers reported that incorporation of an aniline moiety at the place of the $\omega$-isoprene unit of FPP resulted in a transferable analogue. ${ }^{17}$ Recently, successful incorporation of this aniline-GPP (AGPP) analogue was monitored in HEK-293 cells by the use of antibodies raised against the FPP analogue. ${ }^{18}$ Photoaffinity analogues of FPP incorporating a benzophenone moiety or a functionalized aniline moiety were developed by Distefano and Spielmann groups respectively. 19,20,21 FPP analogues appended with fluorescent anthranilate esters were developed by Waldmann and coworkers. ${ }^{22,23}$ Wiemer and coworkers reported synthesis of $N$-alkylated derivatives of GPP as fluorescent labels that are resistant to esterases. ${ }^{24}$ Those compounds were subsequently effectively transferred to peptides and proteins. Distefano and coworkers recently reported that alkynyl ether derivatives of GPP are alternative substrates which can be tethered to other biomolecules after farnesylation. ${ }^{25}$ Prestwich and coworkers synthesized a conjugated GGPP derivative $(\Delta \Delta \mathrm{GG})$ with a conjugated olefinic fluorophore. ${ }^{26}$

Incorporation of a bioorthogonal functional group 27,28 into the FPP structure provides a technique for modifying proteins for subsequent tethering and analysis. We focused our attention on the Staudinger ligation and the $\mathrm{Cu}(\mathrm{I})$ catalyzed Huisgen cycloaddition ("click" reaction), both of which have been used in vivo. A version of the Staudinger ligation, introduced by Bertozzi, ${ }^{29}$ involves intramolecular trapping of a phosphine/azide adduct eventually to give a stable amide linkage. The "click" ligation, introduced by Sharpless 30,31 is a $\mathrm{Cu}(\mathrm{I})$ catalyzed [2.3] cycloaddition reaction between an azide and terminal alkyne to produce a 1,2,3-triazole. We recently reported that proteins derivatized with suitably functionalized analogues of FPP could be readily immobilized on glass slides. ${ }^{32}$ Related approaches were recently reported from the laboratories of Distefano ${ }^{33}$ and Zhao. ${ }^{34}$ We now report the synthesis of a family of azido and alkyne-substituted FPP analogues and their ability to function as alternative substrates for yeast PFTase.

\section{RESULTS AND DISCUSSION}

\section{Synthesis}

We designed a series of azido and alkyne analogues as reagents with which to modify proteins for Huisgen and Staudinger ligations (Figure 2). All of the analogues have a trisubstituted allylic diphosphate moiety in the first isoprene unit, a requirement for all prenyltransferase reactions. Azido-substituted analogues 1-OPP and 4-OPP contain a farnesyl unit, while 3OPP, 5-OPP and 6-OPP contain a geranyl unit. Alkyne substituted analogues include 7OPP and 9-OPP with a propargyl ether moiety and 8-OPP and 10-OPP with propargyl amine. 11-OPP contains an amide-linked alkyne unit. Analogues 1-OPP, 2-OPP, and 4-OPP are derivatives of FPP, while the remaining compounds are derivatives of GPP substituted at the $E \omega$-methyl group. In general, the analogues were prepared from geranyl or farnesyl acetate 
by oxidation of the isoprenoid chain followed by subsequent modification of the oxidized carbon.

Aldehyde 13-OAc was obtained from geranyl acetate (12-OAc) by oxidation with $\mathrm{SeO}_{2} / \mathrm{EtOH}$ followed by hydrolysis as shown in Scheme 1. ${ }^{26}$ Protection of the hydroxyl group with TBSCl gave 13-OTBS. A similar oxidation of farnesyl acetate (14-OAc) by ${ }^{t} \mathrm{BuOOH} / \mathrm{SeO}_{2}$ gave 8hydroxy-and 12-hydroxyfarnesyl acetate (15-OAc and 16-OAc, respectively) in an overall yield of $40 \%$ along with $33 \%$ of unreacted farnesyl acetate (Scheme 2). ${ }^{35,36}$ Alcohol 15OAc was oxidized to aldehyde 17-OAc by treatment with $\mathrm{MnO}_{2}$ under basic conditions that minimized isomerization of the $\omega$-double bond. ${ }^{37}$ Treatment of 14-OAc with NBS followed by $\mathrm{K}_{2} \mathrm{CO}_{3} / \mathrm{MeOH}$ gave the $\omega$-epoxide but hydrolyzed the acetate group, which was subsequently reintroduced under standard conditions. ${ }^{38}$ Epoxy-acetate 18-OAc was treated with periodic acid ${ }^{39}$ to give aldehyde 19-OAc. This aldehyde was converted to silyl-protected 19-OTBS by hydrolysis and treatment with TBS chloride (Scheme 3).

Syntheses of azido analogues 1-OPP and 2-OPP are outlined in Scheme 4. Allylic alcohols 15-OAc and 16-OAc were converted to the corresponding azides 20-OAc and 21-OAc, respectively, by treatment with diphenylphosphorylazidate (DPPA) according to the procedure of Thompson and coworkers. ${ }^{40}$ The acetate group was then hydrolyzed, and the resulting alcohols were phosphorylated as described by Davisson and coworkers 41,42 to give diphosphates 1-OPP and 2-OPP. 1-OPP and 2-OPP were obtained as 1:1 and 2:1 mixtures of their allylic isomers, respectively. Allylic azides undergo a 1,3 rearrangement at room temperature, ${ }^{43}$ and isomerization is seen when azides are synthesized from allylic alcohols. 44,45

The synthesis of azido analogue 3-OPP is shown in Scheme 5. Aldehyde 19-OAc was reduced with sodium borohydride to give alcohol 22-OAc. When 22-OAc was treated with diphenylphosphorylazidate, the phosphate intermediate was not displaced by azide. We then resorted to Lu's method, ${ }^{46}$ which uses a more reactive 2,4 -dichlorophenylphosphate leaving group. When alcohol 22-OAc was treated with bis-(2,4-dichlorophenyl) phosphoryl chloride, DMAP and sodium azide, compound 3-OAc was obtained in high yield. The acetate was hydrolyzed with $\mathrm{K}_{2} \mathrm{CO}_{3}$, and alcohol 3-OH was phosphorylated as described for 1-OPP.

Benzyl azido analogues 4-OPP, 5-OPP and 6-OPP were prepared by the four step sequence shown in Scheme 6. Reductive amination of aldehydes 19-OAc, 17-OAc and 13-OAc by treatment with 3-aminobenzyl alcohol and sodium triacetoxyborohydride ${ }^{21,24,47,48}$ gave good yields of amino alcohols 23-OAc, 24-OAc and 25-OAc, respectively. The benzylic hydroxyl groups were displaced by azide using the Thompson procedure, ${ }^{40}$ followed by acetate hydrolysis and phosphorylation to provide diphosphates 4-OPP, 5-OPP and 6-OPP. Diphosphates 5-OPP and 6-OPP were purified by chromatography on cellulose and characterized. Diphosphate 4-OPP was unstable under these conditions. While we were able to obtain an exact mass for the compound by HRMS, NMR spectra were not suitable for characterization.

Propargyl ethers 7-OPP and 9-OPP were synthesized from aldehydes 13-OTBS and 19OTBS as outlined in Scheme 7. The aldehydes were reduced with sodium borohydride to give alcohols 26-OTBS and 27-OTBS, respectively. Propargyl ether 7-OTBS was prepared by treatment with sodium hydride followed by addition of propargyl bromide. The same procedure gave low yields of 9-OTBS from 27-OTBS. After several attempts, the best yield of the propargyl ether was obtained when potassium hydride was used to deprotonate the alcohol. Half of the starting alcohol was recovered despite using rigorously anhydrous conditions and longer reaction times. The TBS groups were then removed with TBAF and the resulting 
alcohols were phosphorylated as described for the azido analogues to give ethers 7-OPP and 9-OPP.

Propargyl amines 8-OPP and 10-OPP were prepared by reductive amination of aldehydes 13OAc and 19-OAc with propargyl amine using conditions described above for 23-OAc, 24OAc and 25-OAc (Scheme 8). Hydrolysis of the acetate groups, followed by phosphorylation of the resulting alcohols gave modest to good yields of diphosphates 8-OPP and 10-OPP.

Amide analogue 11-OPP was synthesized from alcohol 26-OTBS as outlined in Scheme 9. The hydroxyl group was replaced with a phthalimide moiety using Mitsunobu conditions to give 28-OTBS, ${ }^{49,50}$ which was then treated with hydrazine hydrate followed by propiolic acid in the presence of 1,2-dihydro-2-ethoxy-1-quinolinecarboxylic acid (EEDQ) ${ }^{51}$ to give 11-OTBS. The TBS group was removed with acetic acid in THF: $\mathrm{H}_{2} \mathrm{O}$, and the resulting alcohol was phosphorylated to give 11-OPP in moderate yield.

\section{Kinetic Studies with yeast PFTase}

Recombinant yeast PFTase from an Escherichia coli clone was purified by affinity chromatography on a Ni-NTA column as previously reported. ${ }^{52}$ Details of the enzymatic assays are provided in Supporting Information. Preliminary studies indicated that analogues 1-OPP, 3-OPP, 5-OPP, 6-OPP and 9-OPP were good to excellent alternative substrates for the enzyme. The other analogues were less active and were not characterized further.

Steady state kinetic parameters for the most active analogues with dansyl-GCVIA (DnGCVIA) as a co-substrate are summarized in Table 1 . Two other groups ${ }^{34,53}$ reported that 1OPP is a substrate for PFTase, although a full set of kinetic parameters were not presented. We found that $\mathrm{V}_{\max }$ for the 1:1 mixture of 1-OPP and its allylic isomer (1i-OPP, Scheme 10) is lower than for FPP, although their $K_{M^{S}}$ are similar. The rapid interconversion of the $\omega$ allylic azides (see Scheme 10) prevents us from obtaining the individual kinetic constants for the two isomers. The terminal alkyl azide, 3-OPP, is an excellent substrate with a $\mathrm{k}_{\mathrm{cat}}$ almost equal to that of FPP and a $\mathrm{K}_{\mathrm{M}}$ that is substantially lower, resulting in a 2.1-fold enhancement in catalytic efficiency $\left(\mathrm{k}_{\mathrm{cat}} / \mathrm{K}_{\mathrm{M}}\right)$ over the natural substrate. Clearly, the linear carbon chain in 3-OPP terminated by an azide moiety is a good surrogate for the $\omega$-prenyl unit in FPP. A similar observation was recently reported by Nguyen $e t$. al for an azidopropyl ether analog of FPP. ${ }^{54}$

Our results for 5-OPP are similar to those reported by the Spielmann group for a related psubstituted nitroaniline derivative with rat PFTase, where $\left(\mathrm{k}_{\mathrm{cat}} / \mathrm{K}_{\mathrm{M}}\right)_{\text {rel }}$ was $0.42 .{ }^{21}$ The catalytic efficiency of analogue 6-OPP, with a substantially larger volume in the region of the $\omega$-isoprene unit than 3-OPP, is 14 -fold lower as the result of both a smaller $\mathrm{k}_{\text {cat }}$ and a larger $\mathrm{K}_{\mathrm{M}}$. Although phenyl groups are used as surrogates for the prenyl moiety, 55 we found that the analogues with linear side chains are better alternative substrates. Analogue 9-OPP was the only propargyl derivative with a good kinetic profile, with a catalytic efficiency of $72 \%$ of FPP.

Analogues 2-OPP, 4-OPP, 7-OPP, 8-OPP, 10-OPP and 11-OPP were substantially less reactive or inactive with yeast PFTase in our assay. Most likely these compounds are less compatible with the active site of the enzyme because of branching along the chain or bulk in the chain at the location of the $\omega$-isoprenoid unit in FPP. ${ }^{15,16,56}$ We were somewhat surprised that propargyl ether 7-OPP derived from a geranyl scaffold was a poor substrate in view of a previous report that related benzyl ethers were good analogues for human PFTase. ${ }^{55}$ Recently, Distefano and coworkers used 7-OPP as a substrate to tag proteins, although the rate of farnesylation by the analogue in their assay was poor ( $\sim .08$ of the rate with FPP under the same conditions). ${ }^{26}$ The lack of activity of propargylamino analogues 8-OPP and 10-OPP is understandable given the poor behavior of 7-OPP and the presence of a charged amino group 
in the isoprenoid chain at the $\mathrm{pH}$ of the assay. Both compounds share the same structure except for the heteroatom. Propiolamide analogue 11-OPP is also not active. In addition to being constructed on a geranyl scaffold, the rigidity imposed by the conjugation of the propiolamide may be incompatible with the active site of PFTase. Same behavior has been seen observed for a pentaene analogue of FPP that is not a good substrate for PFTase. ${ }^{57}$ On the other hand, the $\alpha$-azido-acetamide analogue reported by Waldmann, ${ }^{54}$ which does not have restricted rotation, is transferred 37 times more slower that the natural substrate, suggesting that alkylamide moiety is also not optimal.

\section{Characterization of prenylated peptides by HPLC and LC-MS}

The products from prenylation of Dn-GCVIA by each of our five active analogues were established using procedures similar to those previously reported (see Supporting Information). 58 The modified peptides (see Scheme 11) were characterized by HPLC and LC-MS. In each case the HPLC retention time and the mass of the prenylated peptide (Table 2) are consistent with alkylation of the cysteine residue in Dn-GCVIA by the appropriate analogue.

Interestingly, LC-MS trace for $\mathbf{2 9}$ had two closely spaced peaks with the same mass. This suggests that both regioisomers of 1-OPP were incorporated into the peptide or a single isomer, which subsequently rearranged to its allylic isomer, was incorporated. ${ }^{53}$

\section{CONCLUSIONS}

A series of eleven FPP analogues containing biologically orthogonal functional groups as substrates for prenylation of cysteine residues in $\mathrm{C}$-terminal $\mathrm{CaaX}$ recognition sequences by yeast PFTase was synthesized. Five of these were alternative substrates. Four of alternate substrates were azides (1-OPP, 3-OPP, 5-OPP and 6-OPP) and one was an alkyne (9-OPP). Two of the compounds, azide 3-OPP and alkyne 9-OPP, are excellent alternative substrates with respective catalytic efficiencies $(\mathrm{V} / \mathrm{K})$ that are $210 \%$ and $72 \%$ of $\mathrm{V} / \mathrm{K}$ for FPP. We used 3-OPP and 9-OPP to regioselectively modify recombinant versions of green fluorescent protein and glutathione S-transferase that contained a genetically engineered $\mathrm{C}$-terminal $\mathrm{CaaX}$ recognition motif. ${ }^{32}$ The modified proteins were subsequently covalently attached to glass slides derivatized with complementary functional groups using azide-alkyne cycloaddition and the Staudinger ligation. This technology offers promise for attachment of any soluble protein with a C-terminal CaaX motif to a wide variety of substrates.

\section{Experimental Section}

\section{Acetoxydecadienyl alcohol 22-OAc}

$\mathrm{NaBH}_{4}(120 \mathrm{mg}, 3.17 \mathrm{mmol})$ was added in small portions to a solution of aldehyde 19-OAc $(630 \mathrm{mg}, 2.65 \mathrm{mmol})$ in $\mathrm{MeOH}(30 \mathrm{~mL})$ at $-10^{\circ} \mathrm{C}$. The mixture was allowed to stir at $-10^{\circ}$ $\mathrm{C}$ for $2 \mathrm{~h}$ before ice-cold water $(50 \mathrm{~mL})$ was added. Solvent was removed at reduced pressure. The aqueous residue was saturated with solid $\mathrm{NaCl}$ and extracted with ether $(4 \times 15 \mathrm{~mL})$. The combined ether extracts were dried over $\mathrm{Na}_{2} \mathrm{SO}_{4}$ and solvent was removed. The residue was chromatographed to give $495 \mathrm{mg}$ (78\%) of a colorless oil; ${ }^{1} \mathrm{H} \mathrm{NMR}\left(\mathrm{CDCl}_{3}, \delta\right): 5.34$ (d, $J=$ $7.2 \mathrm{~Hz}, 1 \mathrm{H}) ; 5.13(\mathrm{~d}, J=6.3 \mathrm{~Hz}, 1 \mathrm{H}) ; 4.59(\mathrm{~d}, J=6.9 \mathrm{~Hz}, 2 \mathrm{H}) ; 3.63(\mathrm{t}, J=6.3 \mathrm{~Hz}, 2 \mathrm{H}) ; 2.20-2.00$ $(\mathrm{m}, 6 \mathrm{H}) ; 2.06(\mathrm{~s}, 3 \mathrm{H}) ; 1.70(\mathrm{~s}, 3 \mathrm{H}) ; 1.65(\mathrm{~m}, 2 \mathrm{H}) ; 1.61(\mathrm{~s}, 3 \mathrm{H}) ;{ }^{13} \mathrm{C} \mathrm{NMR}\left(\mathrm{CDCl}_{3}, \delta\right): 171.4$, 142.2, 135.3, 124.2, 118.6, 62.7, 61.6, 39.6, 36.0, 30.8, 26.1, 21.2, 16.5, 16.0; IR (neat): 3444 , 2938, 2883, 1738, 1235. HRMS (CI, M+H ${ }^{+}$) Calcd for $\mathrm{C}_{14} \mathrm{H}_{25} \mathrm{O}_{3}$ 241.1804; found 241.1800.

\section{Acetoxydecadienyl azide 3-OAc}

Sodium azide ( $974 \mathrm{mg}, 14.98$ equiv), DMAP (687 mg, 5.62 equiv) and bis-(2,4dichlorophenyl)-chlorophosphonate (1.98 g, 4.87 equiv) were added to a stirred solution of alcohol 22-OAc ( $900 \mathrm{mg}, 3.75$ equiv ) in DMF $(20 \mathrm{~mL})$ at rt. The reaction mixture was allowed 
to stir overnight at $\mathrm{rt}$ before $50 \mathrm{~mL}$ ethyl ether and $50 \mathrm{~mL}$ of brine were added. The layers were allowed to separate. The aqueous layer was diluted with $100 \mathrm{~mL}$ of brine and extracted with ethyl ether $(2 \times 50 \mathrm{~mL})$. The combined ether extracts were washed with water and dried over $\mathrm{MgSO}_{4}$. The solution was filtered, concentrated and the residue was chromatographed to give $933 \mathrm{mg}(94 \%)$ of 3-OAc as a colorless oil; ${ }^{1} \mathrm{H}$ NMR $\left(\mathrm{CDCl}_{3}, \delta\right): 5.34(\mathrm{t}, J=7.2 \mathrm{~Hz}, 1 \mathrm{H}), 5.13$ (t, $J=6.3 \mathrm{~Hz}, 1 \mathrm{H}), 4.58(\mathrm{~d}, \mathrm{~J}=7.2 \mathrm{~Hz}, 2 \mathrm{H}), 3.23(\mathrm{t}, J=6.6 \mathrm{~Hz}, 2 \mathrm{H}), 2.16-2.00(\mathrm{~m}, 6 \mathrm{H}), 2.06(\mathrm{~s}$, $3 \mathrm{H}), 1.70(\mathrm{~s}, 3 \mathrm{H}), 1.68(\mathrm{~m}, 2 \mathrm{H}), 1.60(\mathrm{~s}, 3 \mathrm{H}) .{ }^{13} \mathrm{C} \mathrm{NMR}\left(\mathrm{CDCl}_{3}, \delta\right): 171.3,142.1,134.0,125.1$, 118.6, 61.5, 51.0, 39.5, 36.6, 27.1, 26.2, 21.2, 16.6, 16.0; IR (neat): 2940, 2098, 1741, 1232. HRMS (CI, M+H ${ }^{+}-\mathrm{N}_{2}$ ) Calcd for $\mathrm{C}_{14} \mathrm{H}_{24} \mathrm{NO}_{2}$ 238.1807; found 238.1812.

\section{Decadienol azide 3-OH}

Following the general procedure, acetate 3-OAc $(1.04 \mathrm{~g}, 3.92 \mathrm{mmol})$ was treated with $\mathrm{K}_{2} \mathrm{CO}_{3}(1.63 \mathrm{~g}, 11.76 \mathrm{mmol})$ in $40 \mathrm{~mL}$ of $\mathrm{MeOH}$. Work-up followed by purification via column chromatography gave $876 \mathrm{mg}(100 \%)$ of $\mathbf{3 - O H}$ as a light yellow oil; ${ }^{1} \mathrm{H} \mathrm{NMR}\left(\mathrm{CDCl}_{3}, \delta\right)$ : $5.41\left(\mathrm{dt}, J_{1}=6.9 \mathrm{~Hz}, J_{2}=0.9 \mathrm{~Hz}, 1 \mathrm{H}\right) ; 5.14(\mathrm{t}, J=6.6 \mathrm{~Hz}, 1 \mathrm{H}) ; 4.16(\mathrm{~d}, J=6.6 \mathrm{~Hz}, 1 \mathrm{H}) ; 3.23$ $(\mathrm{t}, J=6.9 \mathrm{~Hz}, 1 \mathrm{H}) ; 2.20-2.00(\mathrm{~m}, 6 \mathrm{H}) ; 1.7(\mathrm{~m}, 2 \mathrm{H}) ; 1.68(\mathrm{~s}, 3 \mathrm{H}) ; 1.60(\mathrm{~s}, 3 \mathrm{H}) ;{ }^{13} \mathrm{C} \mathrm{NMR}$ $\left(\mathrm{CDCl}_{3}, \delta\right): 139.4,133.8,125.2,123.6,59.3,50.9,39.5,36.5,26.9,26.2,16.3,15.9 ;$ IR (neat): $3339,2938,2877,2100,1448,1291,1258$. HRMS (CI, $\left.\mathrm{M}+\mathrm{H}^{+}-\mathrm{N}_{2}\right)$ Calcd for $\mathrm{C}_{12} \mathrm{H}_{22} \mathrm{NO}$ 196.1701; found 196.1683 .

\section{Decadienyl azide diphosphate 3-OPP}

Using the standard phosphorylation protocol, alcohol 3-OH (124 $\mathrm{mg}, 0.56 \mathrm{mmol})$ was converted to the corresponding chloride using NCS $(83 \mathrm{mg}, 0.62 \mathrm{mmol})$ and DMS ( $49 \mu \mathrm{L}$, $0.67 \mathrm{mmol})$. The chloride was then treated with $\left(\mathrm{NBu}_{4}\right)_{3} \mathrm{HP}_{2} \mathrm{O}_{7} .3 \mathrm{H}_{2} \mathrm{O}(1.65 \mathrm{~g}, 1.68 \mathrm{mmol})$, and the product was purified as described to give $127 \mathrm{mg}(53 \%)$ of a white solid; ${ }^{1} \mathrm{H}$ NMR $\left(\mathrm{D}_{2} \mathrm{O}, \delta\right): 5.40(\mathrm{t}, J=7.2 \mathrm{~Hz}, 1 \mathrm{H}) ; 5.19(\mathrm{t}, J=6.6 \mathrm{~Hz}, 1 \mathrm{H}) ; 4.40(\mathrm{t}, J=6.6 \mathrm{~Hz}, 2 \mathrm{H}) ; 3.22(\mathrm{t}, J$ $=6.9 \mathrm{~Hz}, 2 \mathrm{H}) ; 2.20-1.90(\mathrm{~m}, 6 \mathrm{H}) ; 1.66(\mathrm{~s}, 3 \mathrm{H}) ; 1.62(\mathrm{~m}, 2 \mathrm{H}) ; 1.56(\mathrm{~s}, 3 \mathrm{H}) ;{ }^{13} \mathrm{C} \mathrm{NMR}\left(\mathrm{D}_{2} \mathrm{O}\right.$, $\delta): \delta 142.4,134.7,125.6,120.7(J=9.0 \mathrm{~Hz}), 62.8(J=5.0 \mathrm{~Hz}), 51.1,39.7,36.8,27.1,26.6$, 16.3, 15.8; ${ }^{31} \mathrm{P}$ NMR $\left(\mathrm{D}_{2} \mathrm{O}, \delta\right): 6.59(\mathrm{~d}, J=22.6 \mathrm{~Hz}, 1 \mathrm{P}),-10.15(\mathrm{~d}, J=22.6 \mathrm{~Hz}, 1 \mathrm{P})$; HRMS (CI) Calcd for $\mathrm{C}_{12} \mathrm{H}_{22} \mathrm{~N}_{3} \mathrm{O}_{7} \mathrm{P}_{2} 382.0938$, found 382.0937.

\section{Supplementary Material}

Refer to Web version on PubMed Central for supplementary material.

\section{Acknowledgment}

This work was supported by NIH Grant GM21328.

\section{References}

1. Ashar HR, James L, Gray K, Carr D, Black S, Armstrong L, Bishop WR, Kirschmeier P. J. Biol. Chem 2000;275:30451-30457. [PubMed: 10852915]

2. Shields JM, Pruitt K, McFall A, Shaub A, Der CJ. Trends Cell. Biol 2000;10:147-154. [PubMed: 10740269]

3. Sebti SM, Hamilton AD. Oncogene 2000;19:6584-6593. [PubMed: 11426643]

4. Bell IM. J. Med. Chem 2004;47:1869-1878. [PubMed: 15055985]

5. Appels NM, Beijnen JH, Schellens JH. Oncologist 2005;10:565-578. [PubMed: 16177281]

6. Young SG, Meta M, Yang SH, Fong LG. J. Biol. Chem 2006;281:39741-39745. [PubMed: 17090536]

7. Meta M, Yang SH, Bergo MO, Fong LG, Young SG. Trends Mol. Med 2006;12:480-487. [PubMed: 16942914]

8. Buckner FS, Eastman RT, Yokoyama K, Gelb MH, Van Voorhis WC. Curr. Opin. Investig. Drugs 2005;6:791-797. 
9. Gelb MH, Van Voorhis WC, Buckner FS, Yokoyama K, Eastman R, Carpenter EP, Panethymitaki C, Brown KA, Smith DF. Mol. Biochem. Parasitol 2003;126:155-163. [PubMed: 12615314]

10. Glenn MP, Chang SY, Horney C, Rivas K, Yokoyama K, Pusateri EE, Fletcher S, Cummings CG, Buckner FS, Pendyala PR, Chakrabarti D, Sebti SM, Gelb MH, Van Voorhis WC, Hamilton AD. J. Med. Chem 2006;49:5710-5727. [PubMed: 16970397]

11. Nallan L, Bauer KD, Bendale P, Rivas K, Yokoyama K, Horney CP, Pendyala PR, Floyd D, Lombardo LJ, Williams DK, Hamilton A, Sebti S, Windsor WT, Weber PC, Buckner FS, Chakrabarti D, Gelb MH, Van Voorhis WC. J. Med. Chem 2005;48:3704-3713. [PubMed: 15916422]

12. Hucke O, Gelb MH, Verlinde CL, Buckner FS. J. Med. Chem 2005;48:5415-5418. [PubMed: 16107140]

13. Esteva MI, Kettler K, Maidana C, Fichera L, Ruiz AM, Bontempi EJ, Andersson B, Dahse HM, Haebel P, Ortmann R, Klebe G, Schlitzer M. J. Med. Chem 2005;48:7186-7191. [PubMed: 16279776]

14. Harris CM, Poulter CD. Nat. Prod. Rep 2000;17:137-144. [PubMed: 10821108]

15. Strickland CL, Windsor WT, Syto R, Wang L, Bond R, Wu Z, Schwartz J, Le HV, Beese LS, Weber PC. Biochemistry 1998;37:16601-16611. [PubMed: 9843427]

16. Long SB, Hancock PJ, Kral AM, Hellinga HW, Beese LS. Proc. Natl. Acad. Sci. U S A 2001;98:12948-12953. [PubMed: 11687658]

17. Chehade KA, Andres DA, Morimoto H, Spielmann HP. J. Org. Chem 2000;65:3027-3033. [PubMed: 10814193]

18. Troutman JM, Roberts MJ, Andres DA, Spielmann HP. Bioconjugate Chem 2005;16:1209-1217.

19. Turek-Etienne TC, Strickland CL, Distefano MD. Biochemistry 2003;42:3716-3724. [PubMed: 12667062]

20. DeGraw AJ, Zhao Z, Strickland CL, Taban AH, Hsieh J, Jefferies M, Xie W, Shintani DK, McMahan CM, Cornish K, Distefano MD. J. Org. Chem 2007;72:4587-4595. [PubMed: 17477573]

21. Chehade KA, Kiegiel K, Isaacs RJ, Pickett JS, Bowers KE, Fierke CA, Andres DA, Spielmann HP. J. Am. Chem. Soc 2002;124:8206-8219. [PubMed: 12105898]

22. Owen DJ, Alexandrov K, Rostkova E, Scheidig AJ, Goody RS, Waldmann H. Angew. Chem. Int. Ed 1999;38:509-512.

23. Kuhn K, Owen DJ, Bader B, Wittinghofer A, Kuhlmann J, Waldmann H. J. Am. Chem. Soc 2001;123:1023-1035. [PubMed: 11456655]

24. Kim M, Kleckley TS, Wiemer AJ, Holstein SA, Hohl RJ, Wiemer DF. J. Org. Chem 2004;69:81868193. [PubMed: 15549786]

25. Duckworth BP, Zhang Z, Hosokawa A, Distefano MD. ChemBioChem 2007;8:98-105. [PubMed: 17133644]

26. Liu, X-h; Prestwich, GD. J. Am. Chem. Soc 2002;124:20-21. [PubMed: 11772053]

27. van Swieten PF, Leeuwenburgh MA, Kessler BM, Overkleeft HS. Org. Biomol. Chem 2005;3:2027. [PubMed: 15602593]

28. Prescher JA, Bertozzi CR. Nat. Chem. Biol 2005;1:13-21. [PubMed: 16407987]

29. Saxon E, Bertozzi CR. Science 2000;287:2007-2010. [PubMed: 10720325]

30. Rostovtsev VV, Green LG, Fokin VV, Sharpless KB. Angew. Chem. Int. Ed 2002;41:2596-2599.

31. Wang Q, Chan TR, Hilgraf R, Fokin VV, Sharpless KB, Finn MG. J. Am. Chem. Soc 2003;125:31923193. [PubMed: 12630856]

32. Gauchet C, Labadie GR, Poulter CD. J. Am. Chem. Soc 2006;128:9274-9275. [PubMed: 16848430]

33. Duckworth BP, Xu J, Taton A, Guo A, Distefano MD. Bioconjugate Chem 2006;17:967-974.

34. Kho Y, Kim SC, Jiang C, Barma D, Kwon SW, Cheng J, Jaunbergs J, Weinbaum C, Tamanoi F, Falck J, Zhao Y. Proc. Natl. Acad. Sci. U S A 2004;101:12479-12484. [PubMed: 15308774]

35. Li J, Lan J, Liu Z, Li Y. J. Nat. Prod 1998;61:92-95. [PubMed: 9548834]

36. Li Y, Li W, Li Y. J. Chem. Soc., Perkin Trans 1 1993:2953-2956.

37. Xiao XY, Prestwich GD. Synth. Commun 1990;20:3125-3130.

38. Hanzlik RP. Org. Synth 1977;56:112-117.

39. Zoretic PA, Fang H, Ribeiro AA. J. Org. Chem 1998;63:7213-7217. [PubMed: 11672362]

J Org Chem. Author manuscript; available in PMC 2008 November 23. 
40. Thompson AS, Humphrey GR, DeMarco AM, Mathre DJ, Grabowski EJJ. J. Org. Chem 1993;58:5886-5888.

41. Davisson VJ, Woodside AB, Neal TR, Stremler KE, Muehlbacher M, Poulter CD. J. Org. Chem 1986;51:4768-4779.

42. Davisson VJ, Woodside AB, Poulter CD. Methods Enzymol 1985;110:130-144. [PubMed: 2991702]

43. Gagneux A, Winstein S, Young WG. J. Am. Chem. Soc 1960;82:5956-5957.

44. Kale TA, Distefano MD. Org. Lett 2003;5:609-612. [PubMed: 12605471]

45. Feldman AK, Colasson B, Sharpless KB, Fokin VV. J. Am. Chem. Soc 2005;127:13444-13445. [PubMed: 16190677]

46. Yu C, Liu B, Hu L. Org. Lett 2000;2:1959-1961. [PubMed: 10891201]

47. Abdel-Magid AF, Maryanoff CA. Synlett 1990:537-539.

48. Abdel-Magid AF, Carson KG, Harris BD, Maryanoff CA, Shah RD. J. Org. Chem 1996;61:38493862. [PubMed: 11667239]

49. Tago K, Minami E, Masuda K, Akiyama T, Kogen H. Bioorg. Med. Chem 2001;9:1781-1791. [PubMed: 11425580]

50. Turek TC, Gaon I, Gamache D, Distefano MD. Bioorg. Med. Chem. Lett 1997;7:2125-2130.

51. Okonya JF, Kolasa T, Miller MJ. J. Org. Chem 1995;60:1932-1935.

52. Harris CM, Derdowski AM, Poulter CD. Biochemistry 2002;41:10554-10562. [PubMed: 12173942]

53. Rose MW, Rose ND, Boggs J, Lenevich S, Xu J, Barany G, Distefano MD. J. Pept. Res 2005;65:529_ 537. [PubMed: 15885112]

54. Nguyen UTT, Cramer J, Gomis J, Reents R, Gutierrez-Rodriguez M, Goody RG, Alexandrov K, Waldmann H. ChemBioChem 2007;8:408-423. [PubMed: 17279592]

55. Micali E, Chehade KA, Isaacs RJ, Andres DA, Spielmann HP. Biochemistry 2001;40:12254-12265. [PubMed: 11591144]

56. Dunten P, Kammlott U, Crowther R, Weber D, Palermo R, Birktoft J. Biochemistry 1998;37:79077912. [PubMed: 9609683]

57. Liu X-H, Prestwich GD. Bioorg. Med. Chem. Lett 2004;14:2137-2140. [PubMed: 15080995]

58. Dolence JM, Poulter CD. Proc. Natl. Acad. Sci. U S A 1995;92:5008-5011. [PubMed: 7761439]

J Org Chem. Author manuscript; available in PMC 2008 November 23. 
<smiles>[R9]C(NC(=O)C([Ge])NC(=O)C(CS)NC([Y])C(=O)[O-])C(=O)[O-]</smiles>

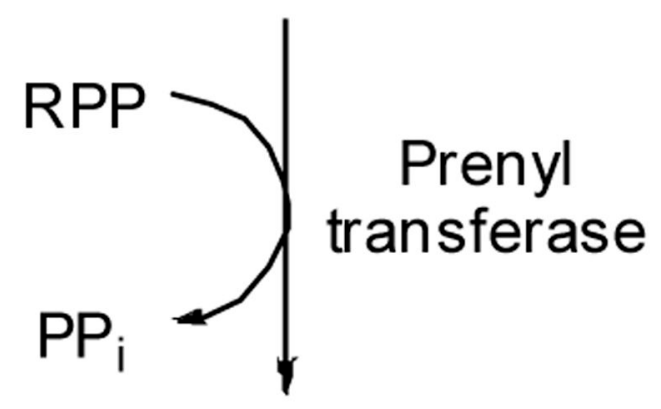<smiles>CC/C=C(\C)CCC=C(C)CC(C)(P)CC=C(C)C</smiles><smiles>[R9]C(NC(=O)C([GaH])NC(=O)C(CS)NC([Y])C(=O)[O-])C(=O)[O-]</smiles>

Enzyme Substrate (R) n

PFTase PGGTase

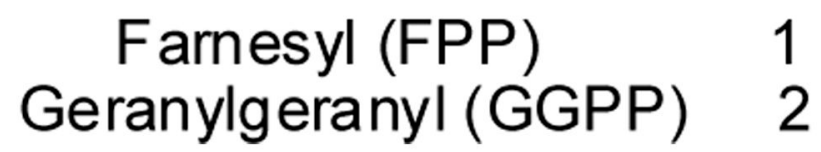

Figure 1.

Reactions catalyzed by PFTase and PGGTase-I. 
<smiles>C/C(=C\CC/C(C)=C/CC/C(C)=C/COc1ccccc1)CC/C=C(\C)CC/C=C(\C)CNc1cccc(CN)c1</smiles><smiles>CC(C)=CCC(N)C(C)C(C)=CCCC(C)=CCOc1ccccc1</smiles><smiles>C/C(=C\COc1ccccc1)CC/C=C(\C)CCCN</smiles><smiles>C/C(=C\COc1ccccc1)CC/C=C(\C)CCCNc1cccc(CN)c1</smiles><smiles>C=CC=C</smiles><smiles>CC(C)=CCC/C(C)=C/CC/C(C)=C/COP(=O)(O)OP(=O)(O)O</smiles>
(FPP)<smiles>C#CCOC/C(C)=C/CC/C(C)=C/COc1ccccc1</smiles><smiles>C#CCOCCC/C(C)=C/CC/C(C)=C/COc1ccccc1</smiles><smiles>C#CCNC/C(C)=C/CC/C(C)=C/COc1ccccc1</smiles><smiles>C#CCNCCC/C(C)=C/CC/C(C)=C/COc1ccccc1</smiles><smiles>C#CC(=O)NCC(C)=CCCC(C)=CCOP</smiles>

Figure 2.

Structures of azido and alkyne FPP analogues 
<smiles>CC(=O)OC/C=C(\C)CC/C=C(\C)C[R9](=O)OCC(=O)OC/C=C(\C)CC/C=C(\C)C=O</smiles>

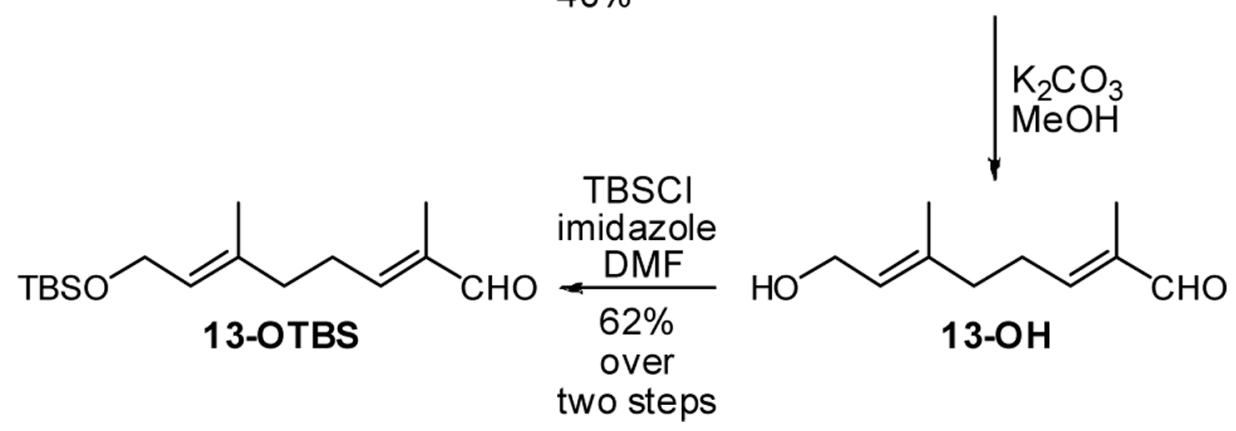

Scheme 1.

Synthesis of aldehyde 13-OAc and 13-OTBS 
<smiles>CC(=O)OC/C=C(\C)CC/C=C(\C)CCC=C(C)C</smiles>

14-OAC

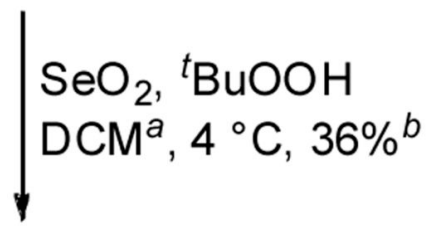<smiles>CC(=O)OC/C=C(\C)CC/C=C(\C)C(O)CC=C(C)C</smiles><smiles>CC(=O)OC/C=C(\C)CC/C=C(\C)CC/C=C(\C)CO</smiles>

15-OAc $(26 \%)$ $\mid \begin{aligned} & \mathrm{MnO}_{2}, \\ & \mathrm{Na}_{2} \mathrm{CO}_{3} \\ & \mathrm{DCM}, 88 \%\end{aligned}$<smiles>CC(=[W])OC/C=C(\C)CC/C=C(\C)CC/C=C(\C)C=O</smiles>

\section{7-OAc}

a Abbreviation: DCM - Dichloromethane; b $33 \%$ farnesyl acetate recovered

Scheme 2.

Synthesis of alcohols 15-OAc and 16-OAc and aldehyde 17-OAc 
<smiles>CC(=O)OC/C=C(\C)CC/C=C(\C)CCC=C(C)C</smiles>

\section{4-OAC}

1. NBS, ${ }^{t} \mathrm{BuOH}: \mathrm{H}_{2} \mathrm{O}, 63 \%$.

2. $\mathrm{K}_{2} \mathrm{CO}_{3}, \mathrm{MeOH}$; then $\mathrm{Ac}_{2} \mathrm{O}, \mathrm{Py}, 96 \%$.<smiles>CC(=O)OC/C=C(\C)CC/C=C(\C)CCC1OC1(C)C</smiles>

\section{8-OAC}<smiles>CC(=O)OC/C=C(\C)CC/C=C(\C)CCC=O</smiles>

\section{9-OAc}

1. $\mathrm{K}_{2} \mathrm{CO}_{3}, \mathrm{MeOH}$

2. TBSCl, imidazole, DMF, $78 \%$.

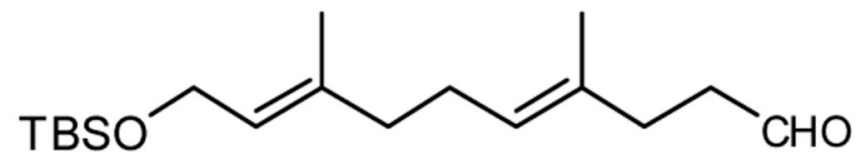

19-OTBS

Scheme 3.

Synthesis of aldehydes 19-OAc and 19-OTBS 
<smiles>[R1]CC(C)=CCC([R])/C(C)=C/CC/C(C)=C/COC(C)=O</smiles>

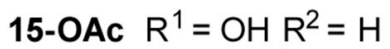

16-OAC $\mathrm{R}^{1}=\mathrm{HR}^{2}=\mathrm{OH}$
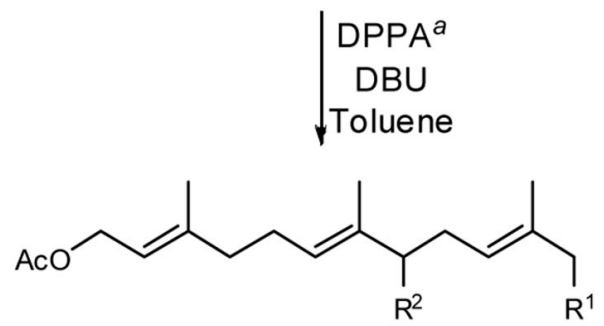

20-OAC $R^{1}=\mathrm{N}_{3} \mathrm{R}^{2}=\mathrm{H} 94 \%$

21-OAC $R^{1}=H^{2} \quad R_{3} 70 \%$ $\mathrm{K}_{2} \mathrm{CO}_{3}$ $\mathrm{MeOH}$<smiles>[R]CC(C)=CCC([R])C(C)=CCCC(C)=CCO</smiles>

1-OH $R^{1}=\mathrm{N}_{3} \mathrm{R}^{2}=\mathrm{H} 91 \%$

2-OH $R^{1}=\mathrm{HR}^{2}=\mathrm{N}_{3} 88 \%$

(i)-DMS ${ }^{a} \mathrm{NCS}, \mathrm{DCM}$

(ii) $\left(\mathrm{NBu}_{4}\right)_{3} \mathrm{HP}_{2} \mathrm{O}_{7}$ Acetonitrile<smiles>[R1]CC(C)=CCC([R])C(C)=CCCC(C)=CCOP</smiles>

1-OPP $R^{1}=\mathrm{N}_{3} \mathrm{R}^{2}=\mathrm{H} 83 \%$ 2-OPP $R^{1}=H^{2}=N_{3} 79 \%$

a Abbreviation : DPPA - Diphenyl phosphoryl azidate;

DMS - Dimethyl sulfide

Scheme 4.

Synthesis of azide analogues 1-OPP and 2-OPP 

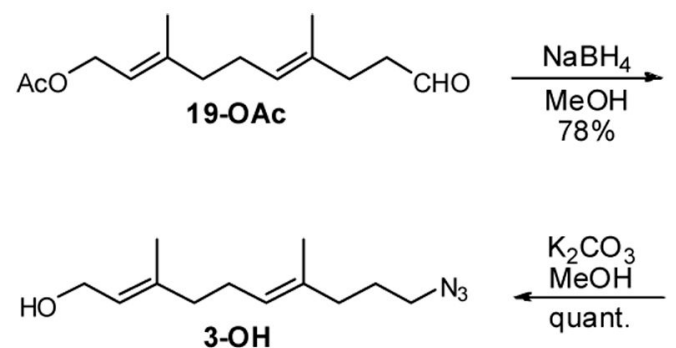

$3-\mathrm{OH}$

(i) DMS, NCS, DCM ${ }^{a}$

(ii) $\left(\mathrm{NBu}_{4}\right)_{3} \mathrm{HP}_{2} \mathrm{O}_{7}$,

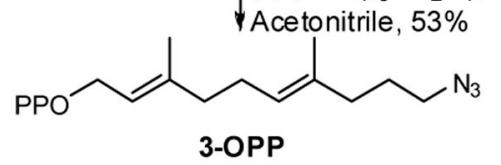

a Abbreviation : DMAP - N,N-Dimethylaminopyridine; DCM - Dichloromethane DMS - Dimethyl sulfide

Scheme 5.

Synthesis of azide analogue 3-OPP

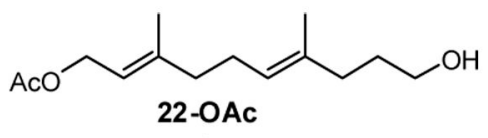

$\left(\mathrm{Cl}_{2} \mathrm{C}_{6} \mathrm{H}_{3} \mathrm{O}\right)_{2} \mathrm{POCl}$ $\mathrm{NaN}_{3}, \mathrm{DMAP}^{a}$, DMF

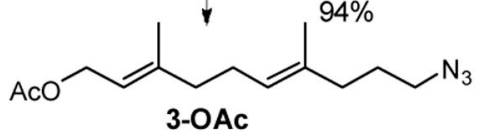




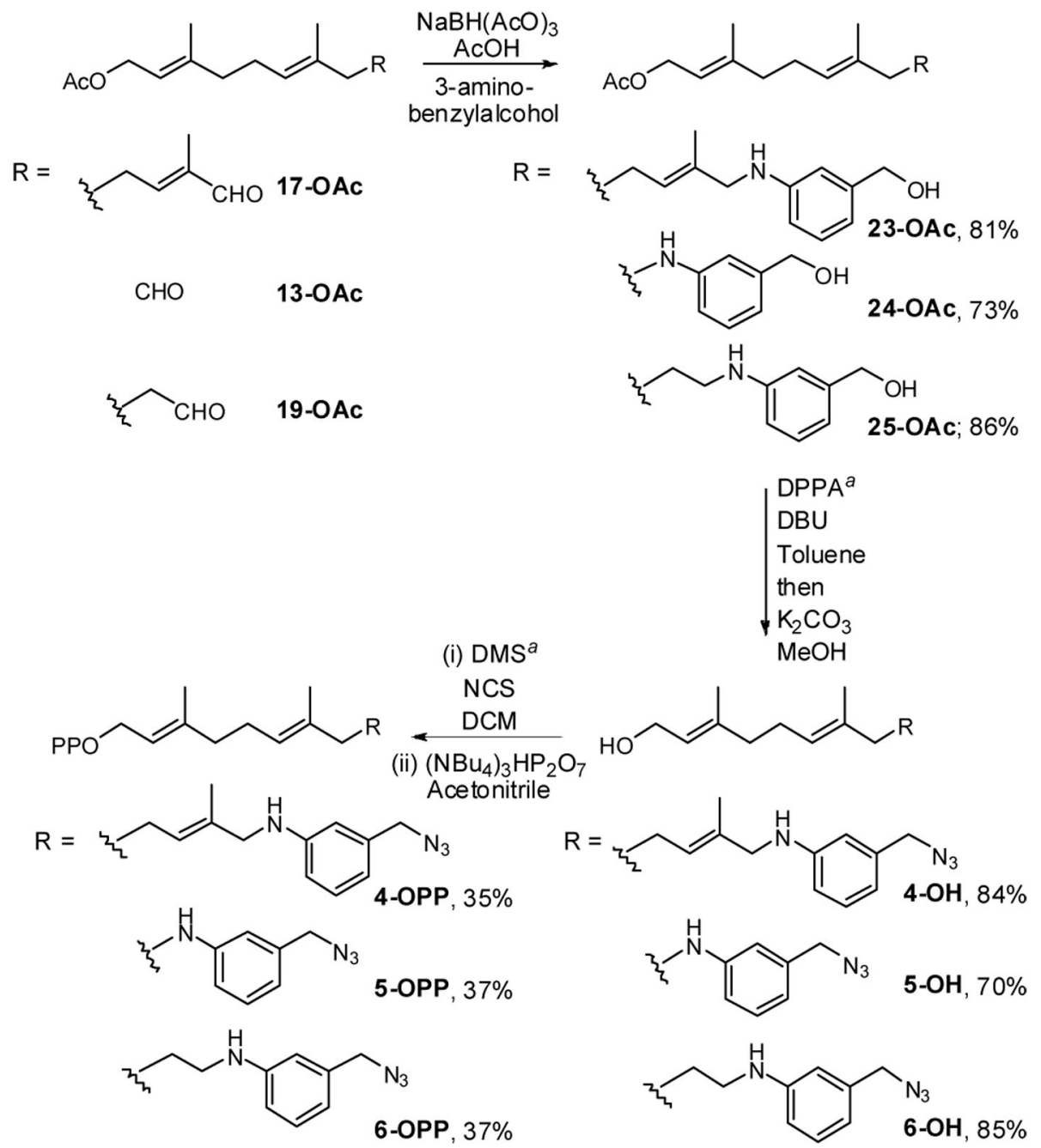

${ }^{a}$ Abbreviation : DPPA - Diphenylphosphorylazide; DMS - Dimethyl sulfide

Scheme 6.

Synthesis of azide analogues 4-OPP, 5-OPP and 6-OPP 


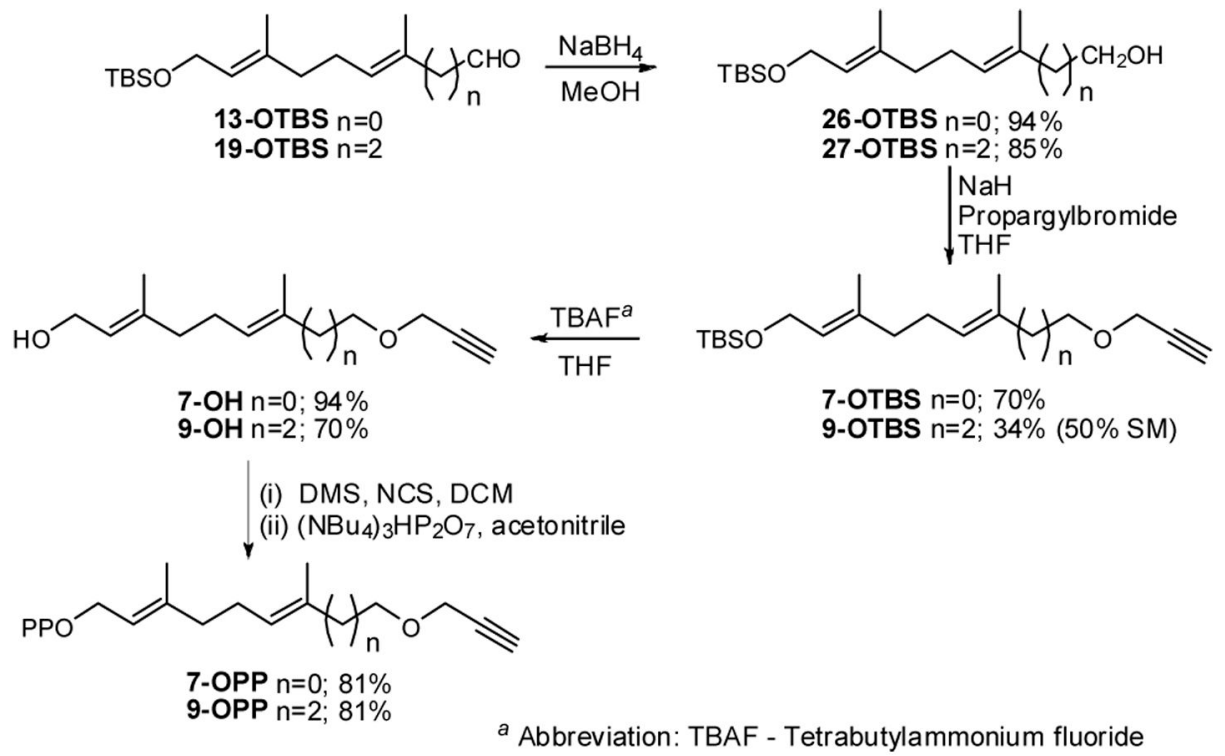

Scheme 7.

Synthesis of alkynyl analogues 7-OPP and 9-OPP 

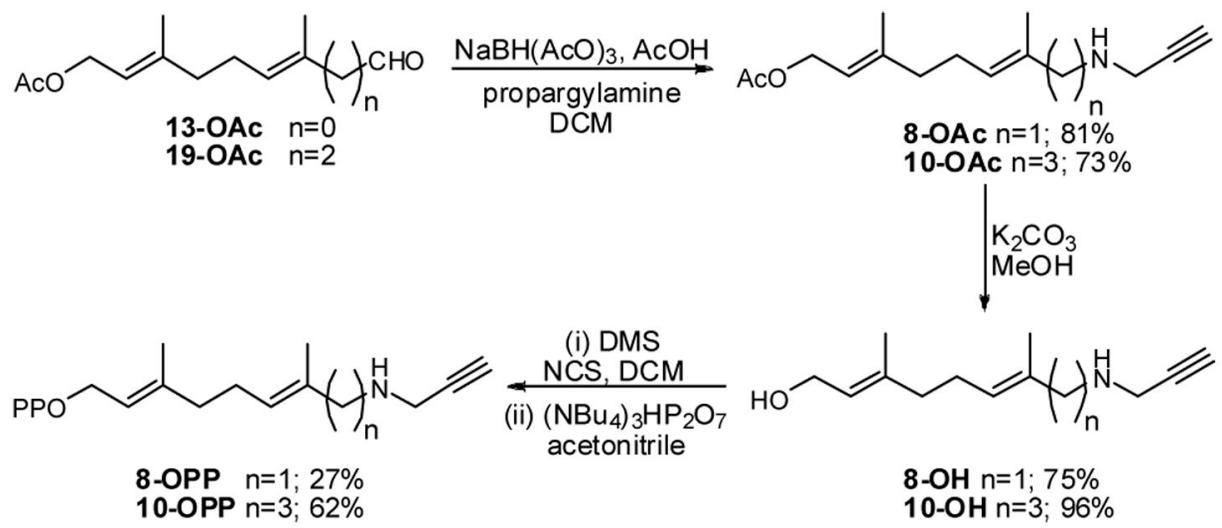

Scheme 8.

Synthesis of alkynyl analogues 8-OPP and 10-OPP 


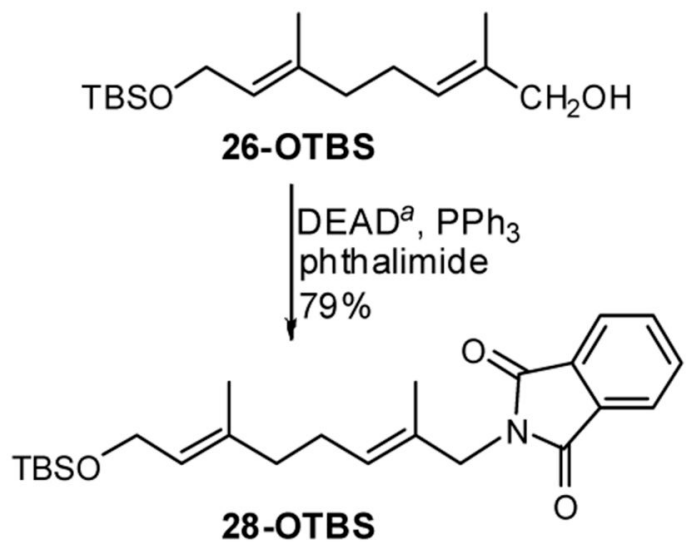

(i) Hydrazine, EtOH

(ii) $E E D Q^{a}$, propiolic acid DCM, 63\%<smiles>C#CC(=O)NC/C(C)=C/CC/C(C)=C/CO[R5](F)(F)F</smiles>
$\mathrm{ACOH}$ THF: $\mathrm{H}_{2} \mathrm{O}, 82 \%$<smiles>C#CC(=O)NC/C(C)=C/CC/C(C)=C/CO</smiles>

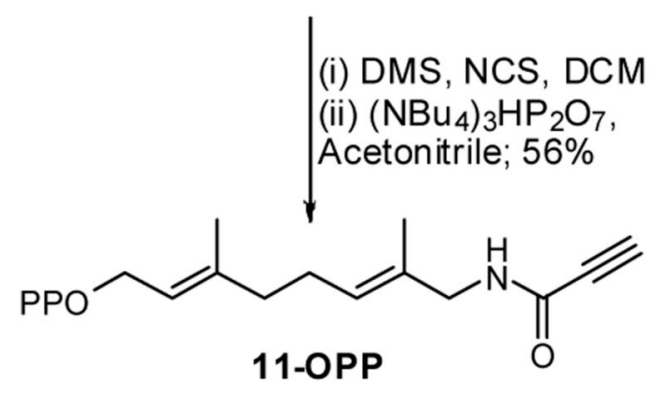

a Abbreviation: DEAD - Diethylazodicarboxylate; EEDQ - 1,2-dihydro-2-ethoxy-1-quinolinecarboxylic acid

Scheme 9.

Synthesis of alkynyl analogue 11-OPP 


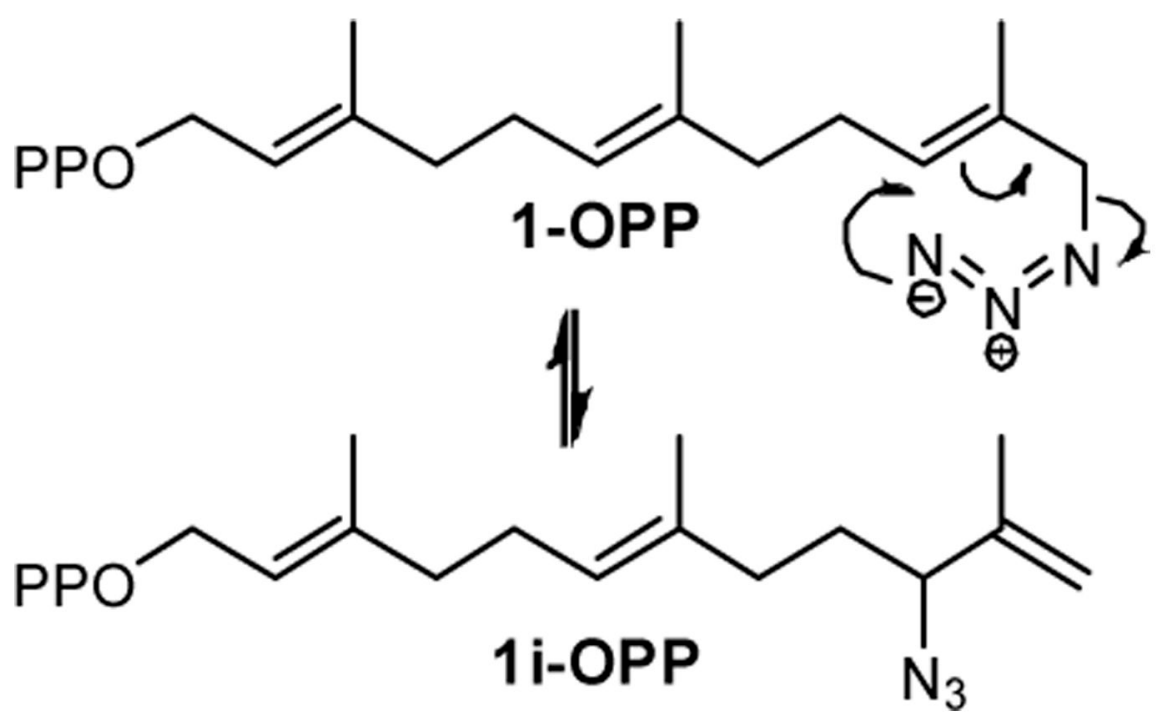

Scheme 10.

1-OPP azide equilibrium 


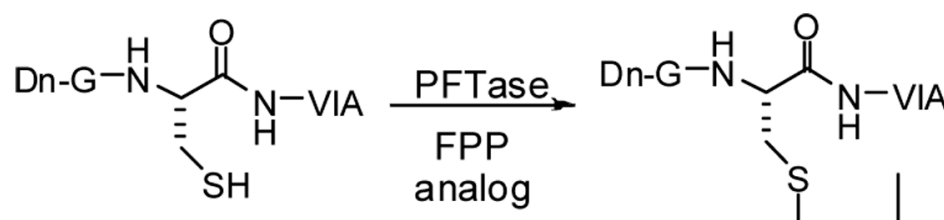
analog<smiles>[R]CCCCCNc1cccc(CN)c1</smiles>

Scheme 11.

Farnesylation of DansylGCVIA with FPP analogues 
Table 1

Steady-State Kinetic Parameters of Active Substrates

\begin{tabular}{|c|c|c|c|c|}
\hline Compound & $\mathbf{k}_{\text {cat }}\left(\mathrm{s}^{-1}\right)$ & $\mathbf{K}_{\mathrm{M}}(\boldsymbol{\mu M})$ & $\mathrm{k}_{\mathrm{cat}} / \mathrm{K}_{\mathrm{M}}\left(\mathrm{s}^{-1} \mu \mathrm{M}^{-1}\right)$ & $\left(\mathbf{k}_{\mathrm{cat}} / \mathrm{K}_{\mathrm{M}}\right)_{\mathrm{rel}}^{a}$ \\
\hline $\begin{array}{c}\text { FPP } \\
\mathbf{1 - O P P}\end{array}$ & $\begin{array}{c}1.31 \pm 0.04 \\
0.45 \pm 0.01 b\end{array}$ & $\begin{array}{l}1.71 \pm 0.04 \\
2.12 \pm 0.15\end{array}$ & $\begin{array}{l}0.77 \\
0.21\end{array}$ & $\begin{array}{c}1 \\
0.28\end{array}$ \\
\hline $\begin{array}{l}\text { 3-OPP } \\
\text { 5-OPP } \\
\text { 6-OPP } \\
\text { 9-OPP }\end{array}$ & $\begin{array}{l}1.10 \pm 0.05 \\
0.35 \pm 0.01 \\
0.48 \pm 0.01 \\
1.06 \pm 0.03\end{array}$ & $\begin{array}{l}0.67 \pm 0.10 \\
1.05 \pm 0.22 \\
4.23 \pm 0.47 \\
1.90 \pm 0.22\end{array}$ & $\begin{array}{l}1.6 \\
0.33 \\
0.11 \\
0.55\end{array}$ & $\begin{array}{l}2.1 \\
0.43 \\
0.15 \\
0.72\end{array}$ \\
\hline
\end{tabular}

${ }^{a} V$ rel refers to $k$ cat $/ K m$ with respect to FPP

$b$ Rate corresponds to the incorporation of both isomers as was shown by HPLC. 
Table 2

HPLC Retention times for Dn-GCVIA and Dn-GC(Far)VIA peptides and LC-Mass molecular ions for the products.

\begin{tabular}{ccc}
\hline Compound & Retention time $(\mathbf{m i n})$ & LC-Mass $\left(\mathbf{M}^{+}+\mathbf{H}\right)$ \\
\hline & & 695.3 \\
Dn-GCVIA & 4.9 & 940.5 \\
$\mathbf{2 9}$ & 19.3 & 900.3 \\
$\mathbf{3 0}$ & 17.5 & 977.4 \\
$\mathbf{3 1}$ & 14.4 & 1005.5 \\
$\mathbf{3 2}$ & 14.8 & 913.6 \\
\hline
\end{tabular}

